\title{
Downflow Hanging Sponge (DHS) Reactor for Wastewater Treatment - A Short Review
}

\author{
Awaluddin Nurmiyanto ${ }^{1, *}$ and Akiyoshi Ohashi ${ }^{2}$ \\ ${ }^{1}$ Department of Environmental Engineering, Universitas Islam Indonesia, Yogyakarta, Indonesia \\ ${ }^{2}$ Department of Civil and Environmental Engineering, Hiroshima University, Hiroshima, Japan
}

\begin{abstract}
A combination of upflow anaerobic sludge blanket (UASB) and downflow hanging sponge (DHS) reactor has emerged as an interesting alternative wastewater treatment process. The combined system not only exhibited good organic removal performance in pilot scale experiment, moreover, several studies in the last decades also showed the good efficiency and robustness of DHS reactor in full-scale operation for wastewater treatment. This paper provides a review on the basic concept, historical process development and application of the DHS reactor for wastewater treatment. Over twenty-year development of DHS technology suggests that DHS reactor had become a viable alternative not only solving the sanitation problems in developing countries but also great further potential development in the field of resources recovery technologies from wastewater.
\end{abstract}

\section{Introduction}

According to the WHO, $40 \%$ of the global population still suffering due to improper sanitation and lack of wastewater treatment facilities that disrupting the quality of water sources [1]. Therefore, there is an urgent need to provide basic, affordable wastewater treatment, especially in developing countries. In this regard, upflow anaerobic sludge blanket reactor (UASB) has been selected as a possible technical solution in developing countries due to its simplicity on operational and maintenance, inexpensive construction, and stable operation without requirements for pumping and electricity [2][3]. Unfortunately, UASB advantages often associated with the favorable environmental conditions for anaerobic bacteria, in a warm region where high temperatures $\left(>25{ }^{\circ} \mathrm{C}\right)$ prevail throughout the year. Moreover, operations of stand-alone UASB reactor are often could not able to produce a high-quality effluent and often does not meet the required water quality standards. To cope with this problem, post-treatment systems are being employed extensively for UASB reactor [4].

Various of commonly used post-treatment configurations for UASB effluent such as stabilization pond, activated sludge, aerobic biofilter, and constructed wetland have been reviewed elsewhere [3][4][5]. Besides percentage removal of some common parameters, some more aspects are also should be considered, like the land requirement, operation and

${ }^{1}$ Corresponding author: awaluddin@uii.ac.id 
maintenance cost, and energy requirement. Those technical and non-technical parameters of the process vary to be applicable in developing countries.

An affordable and promising treatment system namely down-flow hanging sponge (DHS) reactor as a post-treatment in combination with UASB reactor as a pre-treatment has been recently implemented for wastewater treatment in developing countries [6][7][8]. The combined system exhibited a good performance not only in organic removal but also nitrogen [8] and fecal coliform [9], as a result, the effluent quality can sufficiently meet the discharge standards of most of the developing countries. Most importantly, this system does not require any external aeration and thus the cost associated with energy and devices required for aeration in which often becomes an obstacle in developing countries was neglected [10]. Moreover, excess sludge production from the system is negligible compared to conventional activated sludge (CAS) [11] that could significantly reducing the cost for sludge handling process. The present paper emphasizes the basic concept of DHS, historical process development, and application of the DHS reactor for wastewater treatment for more than 20 years of development.

\section{Down Flow Hanging Sponge (DHS) Reactor}

The basic principle of the DHS system is somewhat similar to the trickling filter (TF) process in which the wastewater is supplied at the top of supporting media, and trickles down toward bottom part of the reactor [12]. However, the main difference in the DHS system is that use polyurethane sponge (sponge) as supporting media instead of rock or hard-plastic material [13][14]. During this down-flow process (Fig.1) the wastewater passes through the sponges since these sponge carriers are exposed to air and are not submerged in wastewater, oxygen can easily be diffused from the atmosphere through natural ventilation, and thus obviates the need for external aerating device [10][15].

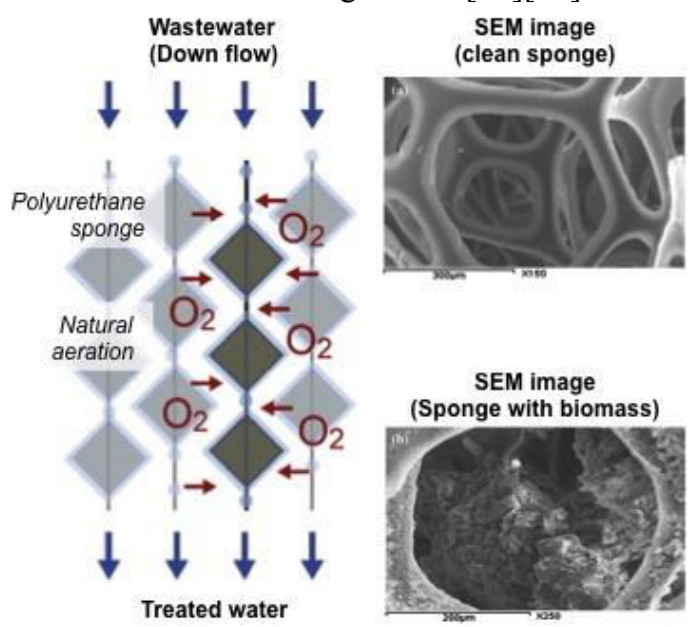

Fig. 1. Basic concept of DHS reactor (image adapted from [8][16])

The sponge has void space more than $90 \%$ [16], and thus created a large surface area which provides an excellent site for microorganisms growth [14][10]. In the conventional TF microorganisms grow only on the surface of supporting media to form a biofilm. In contrast, high porosity of sponge material ensures that active biomass is retained inside and outside of the sponge, which leads to a significant increase in biomass concentration and creates a long sludge resident time (SRT) typically more than 90 days [13][7]. The long SRT also provide adequate time for self-degradation of any attached biomass, reducing the 
production of excess sludge from the process [17][11]. The sponge media also exhibit good water retention in their pores that created a longer hydraulic retention time (HRT) of treated wastewater. It has been proven that DHS can work at extremely long HRT (up to 2 hours) [10][7], henceforth DHS can be built in smaller area compared to the other conventional wastewater treatment process, and the most important is that the sponge is nonbiodegradable material, simple, cheap, and widely available.

Dissolved oxygen (DO) profiles within the DHS reactor have been investigated by using microelectrodes [10][18] and is shown that the outer portion of the sponge is aerobic with sufficient amount of oxygen (DO 4-6 mg/L). Subsequently, the DO concentration decreases toward the center of the sponge until below detection limit, which indicate the existence of anoxic or anaerobic zone in the inner part of the sponge. The oxygen concentration profile implies that both aerobic and anaerobic treatments can be performed in a single DHS reactor, which favorable for denitrification process [8]. Another advantage is that DHS only require electrical energy for wastewater distribution (pump) but not for aeration devices. The estimated energy requirement DHS systems were found to be approximately $75 \%$ lower than CAS [19].

\section{Process Development of DHS Reactor}

DHS originated in Japan since the late 1990's by a research group from Nagaoka Institute of Technology lead by Prof Hideki Harada [20]. Initially, DHS was proposed as an alternative post-treatment process for UASB reactor which does not require any external aeration, simple operation with compact design, and cheap in construction process [10][14]. The DHS system has been intensively evaluated through several pilot-scale experiment in order to develop a more effective performance and practical in the construction process. Different aspect on sponge media design and arrangement were evolved throughout the years and thus named as the first to the sixth-generation of DHS reactor (G1 to G6) [14] as being presented in Fig. 2 [12].

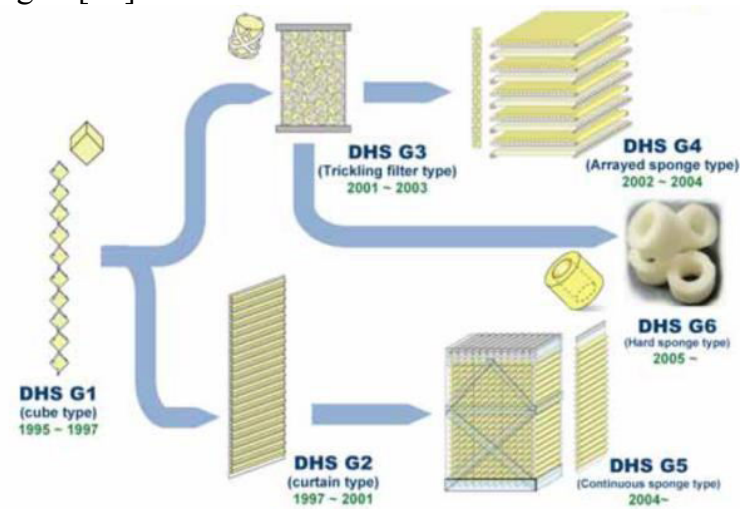

Fig. 2. Historical development of different DHS generation (image source:[12])

Study of DHS was initiated through the development of a hanging cube process, which consisted of a series of cube shape polyurethane sponge $(1.5 \mathrm{~cm}$ each) that connected diagonally using nylon string ( $2 \mathrm{~m}$ height). This process was combined with UASB reactor as pre-treatment and so-called as first-generation DHS (G1)[10]. The first experimental pilot DHS-G1 was undertaken to test performance for organics removal and nitrification merely by natural aeration process. During the six month operation, the whole system exhibit an excellent performance in both organic and nitrogen removal. The combined UASB-DHS system could produce a remarkable water quality with only $2 \mathrm{mg} / \mathrm{L}$ BOD 
remained in the final effluent. However, DHS-G1 seems difficult to be constructed in full scale since cube and strings are mechanically unstable for high rate wastewater. In addition, uniformity of wastewater distribution through the hanging sponge could only be achieved in a laboratory scale.

DHS-G2 was developed to overcome some drawbacks points from the previous generation. The sponge shape was changed from a cube into triangular prisms $(75 \mathrm{~cm}$ in length and triangular sides of $3 \mathrm{~cm}$ ) attached on both sides of a plastic sheet $(2 \mathrm{~m}$ height) to form curtain shape [17]. The DHS-G2 was also assessed as post-treatment unit of UASB reactor fed with real sewage at pilot scale experiment. After 550 days operation, the results showed that DHS-G2 successfully achieved $83 \%$ of T-BOD removal, $94 \%$ of T-COD removal, $67 \%$ of TSS removal, and $40 \%$ of $\mathrm{NH}_{4}-\mathrm{N}$ removal comparable to the DHS-G1 (Table. 1). Nevertheless, the uniformity of wastewater distribution still become a problem in DHS-G2 configuration. Another weak point is that DHS-G2 causing more biomass washout as it easily detached from the curtain like sponge media.

Table 1. Summary of DHS reactor process development

\begin{tabular}{|c|c|c|c|c|c|c|}
\hline & \multicolumn{6}{|c|}{ Generation of DHS } \\
\hline & G1 & G2 & G3 & G4 & G5 & G6 \\
\hline \multicolumn{7}{|l|}{ Construction: } \\
\hline $\begin{array}{l}\text { Sponge } \\
\text { shape/arrangement }\end{array}$ & cube & curtain & $\begin{array}{l}\text { trickling } \\
\text { filter }\end{array}$ & $\begin{array}{l}\text { arrayed } \\
\text { sponge }\end{array}$ & $\begin{array}{l}\text { curtain } \\
\text { module } \\
85 \times 50 \times 5\end{array}$ & $\begin{array}{l}\text { trickling } \\
\text { filter } \\
\varnothing 4.2 \times 3 \text {. }\end{array}$ \\
\hline Sponge size $(\mathrm{cm})$ & $\begin{array}{l}1.5 \times 1.5 \times 1 \\
.5\end{array}$ & $3 \times 3 \times 75$ & $\varnothing 2.7 \times 2.7$ & $\begin{array}{l}2.5 \times 2.5 \times 50 \\
\text { (one } \\
\text { module) }\end{array}$ & $\begin{array}{l}0 \\
\text { (one } \\
\text { module) }\end{array}$ & $\begin{array}{l}7 \\
\text { (internal } \\
\varnothing 0.2 \text { ) }\end{array}$ \\
\hline Sponge volume (L) & 0.3 & 51.3 & 51.6 & 375 & 479 & 46 \\
\hline HRT (h) & $\begin{array}{l}2.4 \\
\text { soft }\end{array}$ & $\begin{array}{l}2 \\
\text { soft }\end{array}$ & 2 & 2 & $\begin{array}{l}2.5 \\
\text { soft }\end{array}$ & $\begin{array}{l}2 \\
\text { rigid }\end{array}$ \\
\hline Sponge type & $\begin{array}{l}\text { sponge } \\
\text { Nylon }\end{array}$ & $\begin{array}{l}\text { sponge } \\
\text { PVC } \\
\text { plastic }\end{array}$ & $\begin{array}{l}\text { soft sponge } \\
\text { Poly- } \\
\text { propylene }\end{array}$ & $\begin{array}{l}\text { soft sponge } \\
\text { Poly- } \\
\text { propylene }\end{array}$ & $\begin{array}{l}\text { sponge } \\
\text { PVC } \\
\text { plastic }\end{array}$ & sponge \\
\hline $\begin{array}{l}\text { Supporting material } \\
\text { Operational }\end{array}$ & string & curtain & plastic net & plastic net & curtain & none \\
\hline temperature $\left({ }^{\circ} \mathrm{C}\right)$ & ambient & 25 & 25 & ambient & ambient & ambient \\
\hline \multicolumn{7}{|c|}{ Removal performance (\%) } \\
\hline T-COD & 94 & 83 & 83 & 91 & 88 & 91 \\
\hline T-BOD & 99 & 94 & 89 & 95 & 94 & 96 \\
\hline SS & 100 & 67 & 82 & 94 & 95 & 91 \\
\hline $\mathrm{T}-\mathrm{N}$ & 17 & 40 & 22 & 23 & 56 & 43 \\
\hline F. Coli & - & 98 & - & $3.3 \log$ & 4.0 Log & 3.1 Log \\
\hline Period (year) & $95-96$ & 96-01 & 01-03 & 02-04 & $04-05$ & $05-08$ \\
\hline Reference & {$[10]$} & [17] & [13] & [22] & [7] & [14] \\
\hline
\end{tabular}

The next generation of DHS reactor was designed little different from the former DHS generation. Trickling filter concept was adopted in the DHS-G3, instead of using gravel or plastic as filter media, it was replaced with small pieces of polyurethane sponge $(2.7 \mathrm{~cm}$ in height) encased in a polypropylene plastic net $(\varnothing 2.7 \mathrm{~cm})$ as a supporting material on the outside [13]. The sponge media was filled into the reactor randomly and this configuration will allow us to upscale the reactor size much easier. The DHS-G3 still operated without any external aeration as the natural air could diffuse through some ventilation in the reactor. Tawfik et al (2006) reported that DHS-G3 not only delivered similar organic removal performance to the former generation but also was capable of removing fecal coliform from 
wastewater [9]. The drawback from DHS-G3 was found in the declining DO concentration followed by a decrease of nitrification activity after several month operations. The random arrangement of sponge media was considered the reason for the lack of air transfer between sponge media inside the reactor.

Table 2. Advantages and drawbacks of DHS reactor

\begin{tabular}{|c|c|}
\hline Advantages & Drawbacks \\
\hline \multicolumn{2}{|l|}{ Construction } \\
\hline 1. Easy construction and expansion & 1. Difficult scale-up (DHS-G1) \\
\hline \multirow[t]{2}{*}{ 2. Compact design, small land required } & 2. Expensive (DHS-G2) \\
\hline & 3. Pre-treatment is required \\
\hline \multicolumn{2}{|l|}{ Supporting media (sponge) } \\
\hline $\begin{array}{l}\text { 1. Durable } \\
\text { 2. Mechanically stable } \\
\text { 3. } 95 \% \text { void to volume ratio }\end{array}$ & 1. Too much water retained \\
\hline \multicolumn{2}{|l|}{ Biomass } \\
\hline 1. High sludge retention time (SRT) & $\begin{array}{l}\text { 1. Biomass will significantly } \\
\text { increase the media weight }\end{array}$ \\
\hline 2. Limited excess sludge produced & $\begin{array}{l}\text { 2. Potential of biomass salughing } \\
\text { off }\end{array}$ \\
\hline \multicolumn{2}{|l|}{ 3. Excellent as cultivation bioreactor } \\
\hline \multicolumn{2}{|l|}{ Operation } \\
\hline $\begin{array}{l}\text { 1. High removal efficiency for organic, nutrients } \\
\text { and pathogen }\end{array}$ & 1. Proper flow distribution required \\
\hline 2. Low hydraulic retention time (HRT) & $\begin{array}{l}\text { 2. Slightly longer compared to the } \\
\text { available technologies }\end{array}$ \\
\hline \multicolumn{2}{|l|}{ 3. Simple process control } \\
\hline \multicolumn{2}{|l|}{ 4. Resistance to shock loads } \\
\hline \multicolumn{2}{|l|}{ 5. No need to backwashing, less maintenance } \\
\hline \multicolumn{2}{|l|}{ 6. Flexible to be combined with various } \\
\hline \multicolumn{2}{|l|}{ Energy requirement } \\
\hline $\begin{array}{l}\text { 1. Required only for pumping process } \\
\text { 2. No need of force aeration }\end{array}$ & \\
\hline
\end{tabular}

The fourth generation of DHS reactor (DHS-G4) was constructed to improve the design arrangement from previous DHS-G3 [21]. A similar sponge and plastic cover of DHS-G3 was used in DHS-G4 but with longer length $(50 \mathrm{~cm})$. Several sponges were then arranged in a row and stacked one above in order to create a gap in hope to provide better air transfer into wastewater, which also should minimizes the sludge accumulation that caused reactor clogging in prior trials [20][12]. The DHS-G4 was constructed with four modules of sponge arrangement, which contained almost 300 sponges unit each, resulting in a total volume of 375 L [21]. The UASB-DHS G4 system exhibited excellent organic removal performance of more than $90 \%$ of total BOD (T-BOD), total COD (T-COD), and suspended solid (SS). However, nitrification efficiency was found to be low $\left(21.3 \% \quad \mathrm{NH}_{4}-\mathrm{N}\right.$ removal). Construction of DHS-G4 from long sponge strip also caused problems. Deformation of sponge module was observed in the reactor; this was due to the bigger load caused the accumulation of active biomass inside the sponge strips over the time.

Tandukar et al [7] made improvements to the sponge arrangement of DHS-G2 for more feasible in reactor scale up. Several DHS curtains were assembled to construct a DHS module of the fifth generation of DHS (DHS-G5) reactor. The DHS-G5 module was then stacked one above the other for the construction of a pilot-scale DHS reactor $(85 \mathrm{~cm} \mathrm{x} 49.5$ $\mathrm{cm} \times 49.5 \mathrm{~cm}$ ). Under this configuration, UASB-DHS system is quite comparable to that of 
conventional activated sludge process. Moreover, the nitrification efficiency also improved by $59.9 \% \mathrm{NH}_{4}-\mathrm{N}$ removal [7]. The main problems for DHS-G5 are the bend of curtain holder and tear off sponge curtain after several months of operation. The low material strength against the load accumulation of DHS curtain after several month operations was considered as the reason for the bending.

The newest DHS design (DHS-G6) reactor has the basic design similar to the trickling filter type of DHS-G3 [21]. However, instead of using a soft polyurethane sponge medium, DHS-G6 use rigid sponge medium by introducing epoxy resin into the polyurethane network structure [14][12]. The rigid sponge was developed in order to simplify the reactor construction since it will not require any support materials, such as rigid plastic case, to prevent sponge deformation. Without the plastic case, more sponge surface area is exposed to wastewater, enhancing the interactions between the wastewater, air, and biomass in the sponge [14]. The result from pilot scale UASB-DHS experiment showed that DHS-G6 performance was comparable with soft-sponge type (G1-G5). However, DHS-G6 have less biomass retained inside the rigid sponge than any soft sponge used in previous studies. Lower, biomass retention in the rigid sponge media is because of lower void volume (at $70 \%$ ) compared to its softer counterpart (>97\%) [14]. The process development and the advantages along with the drawbacks of DHS reactor is being displayed in Table 1 and Table 2 respectively.

\section{Application of DHS Reactor}

Over twenty years, DHS has been well performed for polishing UASB effluent in a pilotscale experiment [7][10][14][22]. Recent studies have shown that DHS reactor exhibited stable performance at full-scale application. Moreover, DHS reactor also have been adopted in several countries, including India [6][8], Egypt [23] and Thailand [24]. The resume performance parameters of DHS for domestic wastewater treatment is presented on Table 3.

Tabel 3. Selected DHS performance data treating domestic wastewater

\begin{tabular}{lllll}
\hline Location & India & India & Egypt & Thailand \\
\hline DHS Type & $\mathrm{G} 2$ & $\mathrm{G} 3$ & $\mathrm{G} 3$ & $\mathrm{G} 3$ \\
\hline Flowrate $\left(\mathrm{m}^{3} \mathrm{~d}^{-1}\right)$ & 500 & 500 & 0.29 & 1.2 \\
Reactor volume $\left(\mathrm{m}^{3}\right)$ & 126 & 126 & 0.056 & 0.11 \\
Sponge occupancy $(\%)$ & 24.7 & 22.3 & 51.3 & 53 \\
\hline Operational condition & & & & \\
\hline Average temperature $\left({ }^{\circ} \mathrm{C}\right)$ & 28 & 28 & 33 & 30 \\
Duration (d) & 1800 & 360 & 2 & 380 \\
HRT (h) & 1.5 & 1.3 & 2 & 1 \\
OLR $\left(\right.$ Kg COD $\left.\mathrm{m}^{-3} \mathrm{~d}^{-1}\right)$ & 2.84 & 2.37 & 1.84 & 1.45 \\
\hline Wastewater quality & & & & \\
\hline T-COD & 430 & 380 & 536 & 60.5 \\
T-BOD & 151 & 130 & 250 & 19.1 \\
SS & 228 & 229 & 220 & 29.4 \\
T-N & 29 & 36 & 48 & 7.3 \\
\hline Removal performance (\%) & & & \\
\hline T-COD & 93 & 91 & 90.4 & 65 \\
T-BOD & 96 & 89 & 95 & 85 \\
SS & 94 & 94 & 96 & 83 \\
T-N & 65 & 32 & 73 & 44 \\
Reference & {$[6][8]$} & {$[22]$} & {$[23]$} & {$[24]$} \\
\hline
\end{tabular}


Several attempts have been made to study the ability of DHS reactor for treating various types of industrial wastewaters. This includes relatively high strength wastewater from molasses based waste from a bioethanol plant with high sulfate content [25] and landfill leachates with high ammonia content [27]. It also applied in the textile wastewater with a noticeable amount of color. The DHS reactor performance on selected industrial wastewater is being displayed on Table 4. Most of the experiments were conducted at the bench scale, and it seems that DHS reactor only delivered limited performance in organic removal. However, the suitability of DHS reactor with another physicho-chemical wastewater treatment process like Fenton oxidation, acidification indicated the potential ability in any other type of wastewater treatment.

Tabel 4. Selected DHS performance data treating industrial wastewater

\begin{tabular}{llll}
\hline Wastewater type & Molasses & Textile Dye & Landfill leachate \\
\hline DHS Type & G2 & G3 & G3 \\
\hline Reactor volume (L) & $\begin{array}{l}21.6 \\
\text { Acidification }\end{array}$ & 50 & 8 \\
& USSB & & $\begin{array}{l}\text { Fenton's } \\
\text { process }\end{array}$ \\
Preprocess & UASB & - & \\
\hline Operational condition & & & 25 \\
\hline Temperature $\left({ }^{\circ} \mathrm{C}\right)$ & 30 & $18-22$ & 1 \\
HRT $(\mathrm{h})$ & 7.4 & $1.7-6$ & \\
\hline DHS influent & & & $2940-5140$ \\
\hline T-COD & 122000 & $505-904$ & NA \\
T-BOD & NA & $107-266$ & \\
pH & 6.1 & $6.85-8.66$ & $8.6-8.9$ \\
\hline DHS Effluent & & & \\
\hline T-COD & 4520 & $404-720$ & $1411-2596$ \\
T-BOD & 47 & $53-133$ & NA \\
pH & $6.8-7.2$ & 8.5 & 8.4 \\
Selected parameter & $80 \%$ sulfate & $44 \%$ color & $85 \%$ ammonia \\
Reference & {$[25]$} & {$[26]$} & {$[27]$} \\
\hline
\end{tabular}

The employment of sponge material as a carrier for active biomass in the DHS also is gaining interest from microbiologist to explore the possibility of DHS for cultivation bioreactor. High porosity in the sponge provides a larger surface area for microbial habitat. In addition, continuous-flow-type cultivation like in the DHS reactor can maintain substrates at low concentrations similar to those found in the natural environment. Continuous-flow also allows the outflow of metabolic products that may inhibit microbial growth if accumulated [29]. Until now, several types of microorganism have been successfully enriched by using DHS reactor, including methanogenic community from subseafloor sediments [29], and different clades of polyphosphate accumulating organisms (PAOs) [30]. In another point of view, Cao et al explore the possibility of production bio$\mathrm{MnO}_{2}$ as an metabolite excess of MnOB in a laboratory scale DHS reactor [31]. This study claimed that $\mathrm{MnOB}$ could be cultivated when coupled with nitrification in a system in which soluble microbial products (SMP) from nitrifiers are provided to $\mathrm{MnOB}$ as a substrate. In this case a biofilm type reactors like DHS may be favorable to the retention of slow-growing nitrifier. After successful $\mathrm{MnOB}$ cultivation, it was reported that produced bio- $\mathrm{MnO}_{2}$ in the sponge is capable for removal recovery of minor metals such as $\mathrm{Ni}$ and Co from wastewater. 
Tabel 5. Recent development in the application of DHS reactor

\begin{tabular}{|c|c|c|c|c|}
\hline Application & $\begin{array}{l}\text { Cultivation } \\
\text { bioreactor }\end{array}$ & $\begin{array}{l}\text { Rare metal } \\
\text { recovery }\end{array}$ & $\begin{array}{l}\text { Phosphate } \\
\text { recovery }\end{array}$ & $\begin{array}{l}\text { Methane } \\
\text { recovery }\end{array}$ \\
\hline DHS Type & G1;G3 & G1 & G3 & G2 \\
\hline Scale & $\mathrm{Lab}$ & $\mathrm{Lab}$ & Pilot & Pilot \\
\hline \multicolumn{5}{|l|}{$\begin{array}{l}\text { Basic } \\
\text { concept }\end{array}$} \\
\hline & $\begin{array}{l}\text { High } \\
\text { porosity in } \\
\text { the sponge } \\
\text { material will } \\
\text { provide an } \\
\text { excellent site } \\
\text { for growth } \\
\text { and } \\
\text { attachment } \\
\text { of active } \\
\text { microbial } \\
\text { communities }\end{array}$ & $\begin{array}{l}\text { DHS reactor used } \\
\text { as the production } \\
\text { of bio- } \mathrm{MnO}_{2} \text { as a } \\
\text { biosorption } \\
\text { compound for } \\
\text { rare metals. }\end{array}$ & $\begin{array}{l}\text { Alternatingly } \\
\text { exposed DHS } \\
\text { reactor under } \\
\text { anaerobic and } \\
\text { aerobic condition } \\
\text { could facilitate the } \\
\text { proliferation of } \\
\text { polyphosphate } \\
\text { accumulating } \\
\text { organisms (PAOs). } \\
\text { The enriche }\end{array}$ & $\begin{array}{l}\text { Two series of } \\
\text { closed DHS } \\
\text { reactor acting } \\
\text { as a biofilter } \\
\text { for the } \\
\text { recovery and } \\
\text { oxidation of } \\
\text { dissolved } \\
\text { methane that } \\
\text { produced in the } \\
\text { UASB reactor. }\end{array}$ \\
\hline Reference & [29] [30] & {$[31]$} & [28] [32] & {$[33][34]$} \\
\hline
\end{tabular}

Phosphorus recovery from wastewaters is important for sustaining agricultural production. However, attaining biological phosphorus removal (BPR) is quite challenging in the attached growth process, since it is difficult to control the sequential aerobic and anaerobic conditions for growth of PAOs. Most of BPR process employed such as suspended growth type like CAS. However in a recent study by Kodera et al (2013) a novel process has been proposed for phosphorus recovery from sewage in the attached biofilm process using DHS reactor [28]. This can be accomplished by modifying the DHS-G3 media with polyester cloth instead of polyurethane sponges. This is, because polyurethane sponge will absorb more water, thus some of the aerobic water still remaines in the carrier, making it difficult to obtain strictly anaerobic condition. The succesful PAOs proliferation in the DHS followed by the accumulation of phosphate concentrated liquid more than 50 mg $\mathrm{P} \mathrm{L} \mathrm{L}^{-1}$ which is considered economically and chemically feasible for struvite crystallization (fertilizer). Up to now a larger scale DHS reactor for has been installed in the Higashihiroshima sewage plant with the daily capacity of $1000 \mathrm{~L}$ in an attempt to recover phosphorus from actual sewage [32].

Another application on the DHS reactor is for purification and recovery of produced methane from UASB. This system was introduced by Matsuura et al [33][34]. It was reported that closed DHS reactor in the first stage could successfully recover an average of $76.8 \%$ of the influent dissolved methane. The remaining dissolved methane is being oxidized in the second stage of closed DHS reactor and polishing of the remaining organic carbons. Current applications of the DHS reactor is presented in Table 5.

\section{Conclusion}

Laboratory and full-scale works has shown that the DHS is capable for treating a variety of wastewaters. The system also exhibits excellent performance that is almost equivalent to that other similar type of attached growth process. Whereas, no need of external aeration in the DHS operation, ensuring the low energy usage and reducing operational cost. Moreover, the flexibility of DHS to be combined with various treatment objectives including resources recovery from wastewater and as cultivation bioreactor indeed gives big advantages than any other similar type of attached growth process. 


\section{References}

1. World Health Organization, Progress on Drinking Water, Sanitation and Hygiene, 166 (2017).

2. C. C. Nnaji, Desalin. Water Treat., 52, 4122-4143, (2013)

3. C. A. L. Chernicharo, Rev. Environ. Sci. Bio/Technology,. 5, 73-92, (2006)

4. A. K. Mungray, Z. V. P. Murthy, and A. J. Tirpude, Desalin. Water Treat., 22, 220237, (2010)

5. A. Khan, Gaur, R.Z., Tyagi, V.K., Khursheed, A., Lew, B., Mehrotra, I., Kazmi, A.A., Resour. Conserv. Recycl., 55, 1232-1251, (2011)

6. T. Okubo, T. Onodera, S. Uemura, T. Yamaguchi, A. Ohashi, and H. Harada, Bioresour. Technol., 194, 156-164, (2015)

7. M. Tandukar, A Ohashi, and H. Harada, Water Res., 41, 2697-705, (2007)

8. T. Onodera, T. Okubo, S. Uemura, T. Yamaguchi, A. Ohashi, and H. Harada, Bioresour. Technol., 204, 77-184, (2016)

9. A. Tawfik, F. El-Gohary, A. Ohashi, and H. Harada, Water Res., 40, 1877-1883, 2006.

10. Machdar, H. Harada, A. Ohashi, Y. Sekiguchi, H. Okui, and K. Ueki, Water Sci. Technol., 36, 189-197, (1997)

11. T. Onodera, Matsunaga, K., Kubota, K., Taniguchi, R., Harada, H., Syutsubo, K., Okubo, T., Uemura, S., Araki, N., Yamada, M., Yamauchi, M., Yamaguchi, T, Bioresour. Technol., 136, 169-175, (2013)

12. Uemura, S., Harada, Application of UASB Technology for Sewage Treatment with a Novel Post-treatment Process, in: H., H. Fang (Eds.), Environmental Anaerobic Technology: Applications and New Developments. Imperial College Press, London, 91-112, (2010)

13. A. Tawfik, A. Ohashi, and H. Harada, Biochem. Eng. J., 29, 210-219, (2006)

14. T. Onodera, M. Tandukar, D. Sugiyana, S. Uemura, A. Ohashi, and H. Harada, Bioresour. Technol., 152, 93-100, (2014)

15. K. Kubota, Hayashi, M., Matsunaga, K., Iguchi, A., Ohashi, A., Li, Y. Y., T. yamaguchi, H. Harada, Bioresour. Technol., 151, 144-150, (2013)

16. A. Tawfik, A. Ohashi, and H. Harada, Bioprocess Biosyst. Eng., 33, 779-785, (2010)

17. Machdar, Y. Sekiguchi, H. Sumino, A. Ohashi, and H. Harada, Water Sci. Technol., 42, 83-88, (2000)

18. N. Araki, A. Ohashi, I. Machdar, and H. Harada, Water Science and Technology, 39, 23-31, (1999)

19. H. Tanaka, M. Takahashi, Y. Yoneyama, K. Syutsubo, K. Kato, A. Nagano, T. Yamaguchi and H. Harada, Water Sci. Technol., 66, 1186-1194, (2012)

20. M. Tandukar, S. Uemura, I. Machdar, A. Ohashi, and H. Harada, Water Sci. Technol., 52, 323-329, (2005)

21. M. Tandukar, S. Uemura, A. Ohashi, and H. Harada, Water Sci. Technol., 53, 209218, (2006)

22. T. Okubo, K. Kubota, T. Yamaguchi, S. Uemura, and H. Harada, Water Res., 102, 138-146, (2016)

23. M. Mahmoud, A. Tawfik, and F. El-Gohary, Chem. Eng. J., 168, 535-543, (2011) 
24. T. Onodera, Yoochatchaval, W., Sumino, H., Mizuochi, M., Okadera, T., Fujita, T., Banjongproo, P., Syutsubo, K, Bioprocess Biosyst. Eng., 37, 2281-2287, (2014).

25. T. Onodera, Sase, S., Choeisai, P., Yoochatchaval, W., Sumino, H., Yamaguchi, T., Ebie, Y., Xu, K., Tomioka, N., Mizuochi, M., Syutsubo, K, Bioresour. Technol., 131, 295-302, (2013)

26. A. Tawfik, D. F. Zaki, and M. K. Zahran, J. Ind. Eng. Chem., 20, 2059-2065, (2014)

27. S. Ismail and A. Tawfik, Water Sci. Technol., 73, 1700-1708, (2016)

28. H. Kodera, M. Hatamoto, K. Abe, T. Kindaichi, N. Ozaki, and A. Ohashi, Water Res., 47, 2025-32, (2013)

29. H. Imachi, Aoi, K., Tasumi, E., Saito, Y., Yamanaka, Y., Yamaguchi, T., Tomaru, H., Takeuchi, R., Morono, Y., Inagaki, F., Takai, K, Isme j, 5, 1913-1925, (2011)

30. A. Nurmiyanto, H. Kodera, T. Kindaichi, N. Ozaki, Y. Aoi, and A. Ohashi, Microbes Environ., 32, 260-267, (2017)

31. T. T. Cao Kodera, H., Abe, K., Imachi, H., Aoi, Y., Kindaichi, T., Ozaki, N., Ohashi, A, Water Res., 68, 545-553, (2015)

32. A. Nurmiyanto, H. Kodera, T. Kindaichi, and N. Ozaki, Phosphorus Recovery from Sewage in a Pilot-Scale UASB-DHS System. In G. Manina (Eds.), Frontiers in Wastewater Treatment and Modelling" FICWTM 2017. Lecture Notes in Civil Engineering, 4. Springer, 22-29, (2017)

33. N. Matsuura, M. Hatamoto, H. Sumino, K. Syutsubo, T. Yamaguchi, and a Ohashi, Water Sci. Technol., 61, 2407-15, (2010)

34. N. Matsuura, M. Hatamoto, H. Sumino, K. Syutsubo, T. Yamaguchi, and A. Ohashi, J. Environ. Manage., 151, 200-209, (2015) 